\title{
Isolation and characterization of a virus (CVV-BW1) that infects symbiotic algae of Paramecium bursaria in Lake Biwa, Japan
}

\author{
Ryo Hoshina ${ }^{1,2}$, Mayumi Shimizu², Yoichi Makino², Yoshihiro Haruyama², Shin-ichiro Ueda ${ }^{2}$, Yutaka Kato²,
} Masahiro Kasahara ${ }^{2,3}$, Bun-ichiro Ono ${ }^{1,2}$, Nobutaka Imamura ${ }^{2,4^{*}}$

\begin{abstract}
Background: We performed an environmental study of viruses infecting the symbiotic single-celled algae of Paramecium bursaria (Paramecium bursaria Chlorella virus, PBCV) in Lake Biwa, the largest lake in Japan. The viruses detected were all Chlorella variabilis virus ( $C V V=N C 64 A$ virus). One of them, designated CVV-BW1, was subjected to further characterization.

Results: CVV-BW1 formed small plaques and had a linear DNA genome of $370 \mathrm{~kb}$, as judged by pulsed-field gel electrophoresis. Restriction analysis indicated that CVV-BW1 DNA belongs to group $\mathrm{H}$, one of the most resistant groups among CVV DNAs. Based on a phylogenetic tree constructed using the dnapol gene, CVV was classified into two clades, A and B. CVV-BW1 belonged to clade B, in contrast to all previously identified virus strains of group $\mathrm{H}$ that belonged to clade $A$.
\end{abstract}

Conclusions: We conclude that CVV-BW1 composes a distinct species within C. variabilis virus.

\section{Background}

Chlorella virus that infects Chlorella-like algae symbiotic with coelenterate Hydra viridis was first discovered in 1981 and designated HVCV (Hydra viridis Chlorella virus) [1]. Subsequently, another Chlorella virus that infects Chlorella-like algae symbiotic with ciliate Paramecium bursaria was described (Paramecium bursaria Chlorella virus [PBCV]) [2]. Studies on HVCV and $\mathrm{PBCV}$ have revealed strong host-parasite relationships [[3] and references therein]: HVCVs do not infect $P$. bursaria symbionts, whereas PBCVs do not infect hydra symbionts; PBCVs collected in the United States infect algal strain NC64A (representative of U.S. P. bursaria symbionts) and other U.S. P. bursaria symbionts, but they do not infect algal strain Pbi (representative of German P. bursaria symbionts) or other European P. bursaria symbionts; PBCVs collected in Europe infect European P. bursaria symbionts but do not infect U.S.

\footnotetext{
*Correspondence: imamura@ph.ritsumei.ac.jp

2Department of Bioscience and Biotechnology, Faculty of Science and Engineering, Ritsumeikan University, Noji Higashi 1-1-1, Kusatsu, 525-8577 Japan

Full list of author information is available at the end of the article
}

P. bursaria symbionts (Fig. 1). Later, another group of viruses that infect Chlorella-like algae symbiotic with heliozoon, Acanthocystis turfacea was described [4]. Chlorella viruses studied to date, therefore, can be divided into four categories: $\mathrm{HVCV}, \mathrm{NC64A}$ virus, $\mathrm{Pbi}$ virus, and ATCV (Acanthocystis turfacea Chlorella virus). Furthermore, none of the Chlorella viruses infect free-living green algae, and NC64A viruses exhibit a degree of diversification with regard to, for example, plaque size, hyaluronan productivity, and DNA methylation level. Note that viruses attack isolated (or released) algae but not algae inhabiting their hosts (i.e., hydra or paramecium).

Recent taxonomic studies on P. bursaria symbionts indicated that the algal group "American" containing strain NC64A and the algal group "European" containing strain $\mathrm{Pbi}$ are genetically distinct from each other, as well as from any known free-living algae and other symbiotic algal species [5]. Consequently, each group has been given a distinct species name, Chlorella variabilis ("American") and Micractinium reisseri ("European") [6]. Due to the defects in taxonomy of the host algae, circular virus names (i.e., Hydra viridis Chlorella virus [HVCV], Paramecium 


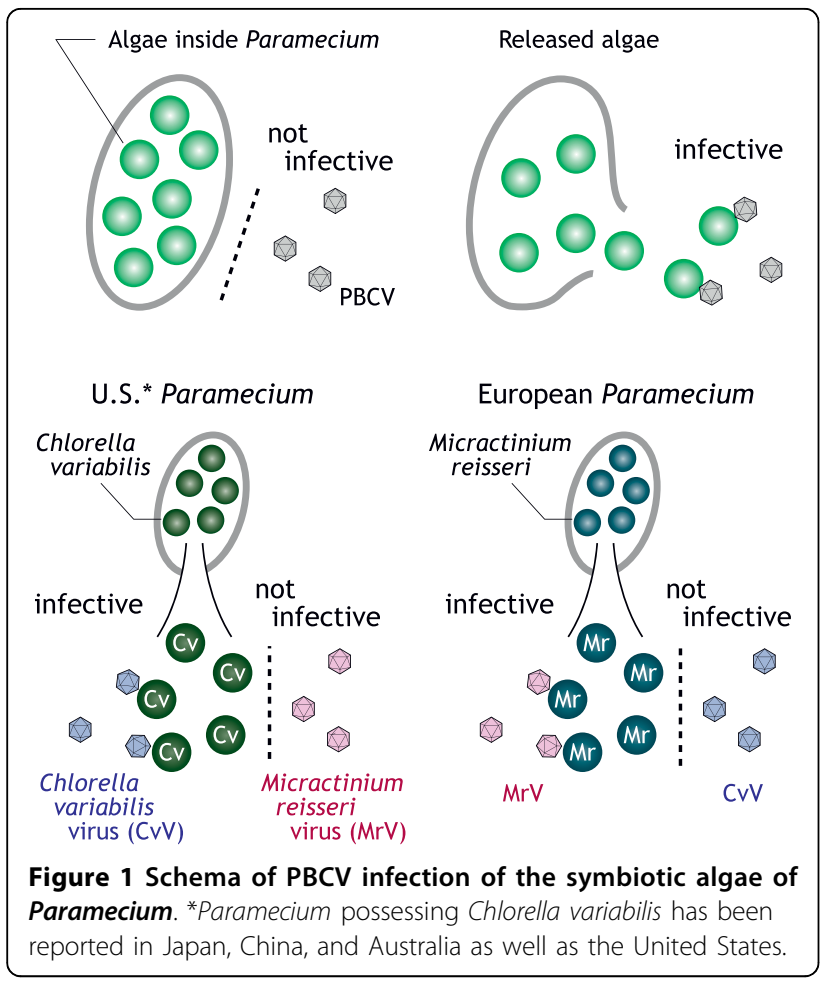

bursaria Chlorella [PBCV], and Acanthocystis turfacea Chlorella virus [ATCV]) and strange names based on host strains (i.e., NC64A virus and Pbi virus) have been used. In this report, viruses infecting $C$. variabilis and $M$. reisseri are referred to as $C$. variabilis virus $(\mathrm{CvV})$ and $M$. reisseri virus (MrV), respectively (Fig. 1).

Chlorella variabilis F36-ZK isolated from Japanese P. bursaria [7] and M. reisseri SW1-ZK isolated from German P. bursaria [8] are lesser-known hosts in PBCV studies, although they are well researched strains in phylogenetic studies $[9,10]$. We carried out a screen for viruses from Lake Biwa and adjacent water environments using C. variabilis F36-ZK and M. reisseri SW1$\mathrm{ZK}$ as hosts. Here, we present the results of the environmental study and the results of a biological study of one strain, CvV-BW1, obtained in the environmental study.

\section{Methods}

\section{Algal strains and culture conditions}

Chlorella variabilis F36-ZK (NIES-2540) and NC64A (ATCC 50258) were cultured in C liquid medium [11] with $200 \mathrm{mg} \mathrm{L}^{-1}$ arginine, while $M$. reisseri SW1-ZK was cultured in $C$ liquid medium with $1 \mathrm{~g} \mathrm{~L}^{-1}$ casamino acid. They were maintained under fluorescent illumination (16 L:8 D, $50 \mu \mathrm{mol}$ photons $\mathrm{m}^{-2} \mathrm{~s}^{-1}$ ) at $25^{\circ} \mathrm{C}$.

\section{Detection of viruses}

Water samples were collected from eight sites at Lake Biwa (the largest lake in Japan) and the adjacent Lake
Yogo. For four sites at Lake Biwa, sampling was carried out almost every month to observe seasonal variations in the virus populations. Water samples were centrifuged at $48,000 \times g$ for $30 \mathrm{~min}$, and then virus concentrated waters were filtrated through nitrocellulose membrane (pore size, $0.45 \mu \mathrm{m}$ ). Whether cultures contained the viruses was determined by mixing with C. variabilis F36-ZK or M. reisseri SW1-ZK liquid cultures on 48 -well microplates. The titers $\left(\mathrm{PFU} \mathrm{mL} \mathrm{mL}^{-1}\right)$ of virus-containing cultures were determined by serial dilution.

\section{Plaque assay and virus isolation}

We followed a previously described plaque assay procedure [12] using $C$ medium with $5 \mathrm{~g} \mathrm{~L}^{-1}$ glucose and $200 \mathrm{mg} \mathrm{L}^{-1}$ serine (CGS) in place of modified Bold's basal medium (MBBM). Plaques were observed after 3 days of cultivation. Single plaques were picked up and transferred to fresh algal lawn plates. Single virus strains were established by repeating this procedure several times.

\section{Electric microscopic observation}

Chlorella variabilis was incubated for $2 \mathrm{~h}\left(25^{\circ} \mathrm{C}\right)$ after adding cultured virus, then fixed with $3 \%$ glutaraldehyde and subsequently with $0.5 \%$ osmic acid. Resin-embedded specimens were cut into ultrathin sections, stained with $3 \%$ uranyl acetate, and then observed under an electron microscope at an acceleration voltage of $75 \mathrm{kV}$.

Another culture was centrifuged at $5000 \times g$ for $5 \mathrm{~min}$, and the resulting supernatant was dropped onto Veco H-200 mesh (Electron Microscopy Sciences, Hatfield, PA, USA), stained with $1 \%$ uranyl acetate, and then observed at $75 \mathrm{kV}$.

\section{SDS-PAGE analysis}

Chlorella variabilis-CvV-BW1 culture mixture was first centrifuged at $12,000 \times g$ for $10 \mathrm{~min}$ to remove algal debris, and the supernatant was centrifuged at $37,000 \times$ $g$ for $1 \mathrm{~h}$ to precipitate virus particles. Urea was added to the precipitate at a final concentration of $4 \mathrm{M}$. After incubation at $45^{\circ} \mathrm{C}$ for $1.5 \mathrm{~h}$, the mixture was centrifuged at $37,000 \times g$ for $10 \mathrm{~min}$ to remove the precipitate. The supernatant was subjected to standard SDS-PAGE analysis; $4.5 \%$ and $7.5 \%$ polyacrylamide gels were used for condensation and separation, respectively. Electrophoresis was performed at a constant voltage of $200 \mathrm{~V}$ using a tank buffer consisting of $0.1 \%$ SDS, $192 \mathrm{mM}$ glycine, and $25 \mathrm{mM}$ Tris.

\section{$\mathrm{N}$-terminal amino acid sequence analysis and amino acid} sequence homology search

After SDS-PAGE, proteins in the polyacrylamide gels were electroblotted onto polyvinylidene fluoride 
membranes (Amersham Biosciences, Piscataway, NJ, USA) using a Horizeblot apparatus (Atto, Tokyo, Japan) at a constant current of $0.8 \mathrm{~mA} \mathrm{~cm}^{-2}$ for $1 \mathrm{~h}$. After staining the membrane with $0.1 \%$ Ponceau solution, bands of interest were cut out and subjected to N-terminal amino acid sequencing using a PPSQ-21/23 peptide sequencer (Shimadzu, Kyoto, Japan); in the present study, $15 \mathrm{~N}$-terminal amino acids were examined. Using the obtained 15 amino acid sequence, a homology search was carried out using NCBI protein-protein BLAST http://www.ncbi.nlm.nih.gov/BLAST/.

\section{Pulsed-field gel electrophoresis (PFGE)}

An equal volume of $1.4 \%$ InCert Agarose $\left(45^{\circ} \mathrm{C}\right.$; BioRad, Hercules, CA, USA) was added to a suspension of Chlorella virus, and the mixture was poured into a mold and solidified by cooling at room temperature. An agar block was removed from the mold, soaked in cell wall-dissolving solution $\left(1 \mathrm{mg} \mathrm{mL} L^{-1}\right.$ proteinase $\mathrm{K}$, $1 \%$ lauroyl sarcosinate, $0.01 \mathrm{M}$ Tris- $\mathrm{HCl}, \mathrm{pH} 8.0$ ), and incubated at $50^{\circ} \mathrm{C}$ for $16 \mathrm{~h}$. The mixture was discarded, and fresh mixture was supplied and incubated at $50^{\circ} \mathrm{C}$ for $24 \mathrm{~h}$. After incubation at $4^{\circ} \mathrm{C}$ for 2 days in TE buffer (10 mM Tris-HCl, pH 8.0, containing $0.1 \mathrm{mM}$ EDTA), the gel block was subjected to PFGE using 1\% Seakem GTG agarose (Bio-Rad) and a CHEF-DRIII system (Bio-Rad). Tank buffer ( $89 \mathrm{mM}$ Tris- $\mathrm{HCl}, \mathrm{pH}$ 8.0, containing $2 \mathrm{mM}$ EDTA and $89 \mathrm{mM}$ boric acid) was used. Electrophoresis was performed at $14^{\circ} \mathrm{C}$. Other conditions were as follows: switching time, 22 to $50 \mathrm{~s}$; total time, $24 \mathrm{~h}$; voltage, $6.6 \mathrm{~V} \mathrm{~cm}^{-1}$. Saccharomyces cerevisiae chromosomes (Bio-Rad) and $\lambda$ DNA ladder (Bio-Rad) were used as size markers.

\section{Extraction of CvV-BW1 DNA}

Five units of DNase I was added to the virus particles (precipitate) described above. The resultant precipitate was suspended, and the suspension was incubated at $37^{\circ} \mathrm{C}$ for $1 \mathrm{~h}$. Proteinase $\mathrm{K}$ to at a final concentration of $1 \mathrm{mg} \mathrm{mL}{ }^{-1}$, EDTA to $0.1 \mathrm{M}$, and SDS to $0.5 \%$ were then added to the suspension. After incubation at $60^{\circ} \mathrm{C}$ for $1 \mathrm{~h}$, the mixture was subjected to the standard phenol extraction procedure [13].

\section{Digestion of CvV-BW1 DNA with restriction enzymes}

Restriction enzymes were purchased from Takara Bio (Otsu, Japan) and/or Nippon Gene (Tokyo, Japan). Restriction enzymes were used under the conditions recommended by the manufacturers.

\section{HPLC analysis of methylated nucleotides}

CrV-BW1 DNA was mixed with Nuclease P1 (GC Analysis Standard Kit; Yamasa, Choshi, Japan). The mixture was incubated at $50^{\circ} \mathrm{C}$ for $1 \mathrm{~h}$. After digestion, the mixture was subjected to HPLC using a column of ODSYMC PACK AQ-312 $(6.0 \mathrm{~mm}$ in inner diameter and $150 \mathrm{~mm}$ in length) (YMC, Kyoto, Japan). HPLC conditions and peak assignment were adopted from Kowalak et al. [14] and Ushida et al. [15].

\section{Hyaluronan labeling}

Hyaluronan labeling was performed according to a modification of the technique reported by Graves et al. [16] and Cohen et al. [17]. Chlorella variabilis F36-ZK was incubated for $2 \mathrm{~h}\left(25^{\circ} \mathrm{C}\right)$ after adding viruses, of which $200 \mu \mathrm{L}$ was centrifuged at $5000 \times g$ for $5 \mathrm{~min}$. Cells were fixed in phosphate-buffered saline (PBS) with 3\% paraformaldehyde for $20 \mathrm{~min}$. Centrifugation and PBS wash were repeated three times. Then, cells were incubated for $2 \mathrm{~h}$ at $37^{\circ} \mathrm{C}$ with $20 \mu \mathrm{L}$ of biotinylated hyaluronic acid binding protein (bHABP, $0.5 \mathrm{mg}$ $\mathrm{mL}^{-1}$; Seikagaku, Tokyo, Japan). Centrifugation and PBS wash were repeated three times, followed by incubation with $50 \mathrm{~mL}$ of CY3-conjugated streptavidin (1.8 $\mathrm{mg} \mathrm{mL} \mathrm{L}^{-1}$; ENCO, Petach Tikva, Israel) for $30 \mathrm{~min}$ at $37^{\circ} \mathrm{C}$. Centrifugation and PBS wash were repeated three times, and then cells were observed under a fluorescence microscope with excitation at 510 to 550 $\mathrm{nm}$.

\section{DNA polymerase gene analyses}

The DNA polymerase gene (dnapol) region was amplified using the forward primer M37dpo0310F (5'CAA TGG TGC AAT TCG TGT TC-3') and reverse primer M37dpo2390R (5'-GTG AAT TTT TCC ATG GGA TAC TC-3'). These primers were designed with reference to three longer determined sequences of PBCV-1 (M86836), NY-2A (M86837), and CVK2 (AB011500). A standard three-step PCR protocol was carried out (annealing temperature of $55^{\circ} \mathrm{C}$ ) using Takara Ex Taq (Takara Bio) according to the manufacturer's directions. The PCR product was confirmed by agarose gel electrophoresis, purified by polyethylene glycol (PEG) precipitation, and then sequenced directly.

The obtained sequence was compared to those of Chlorella viruses available in the databases. The alignment was performed with reference to Zhang et al. [18], and 663 nucleotide positions (Polymerase Domain, excluding introns) contributed to phylogenetic analysis. Phylogenetic tree was constructed by the neighbor-joining (NJ) methods of Saito and Nei's evolutionary model using Clustal X ver. 2 [19]. The significance of each node was tested using 1000 bootstrap replicates. Evolutionary divergence between sequences was estimated using the Jukes-Cantor method in MEGA4 [20]. 


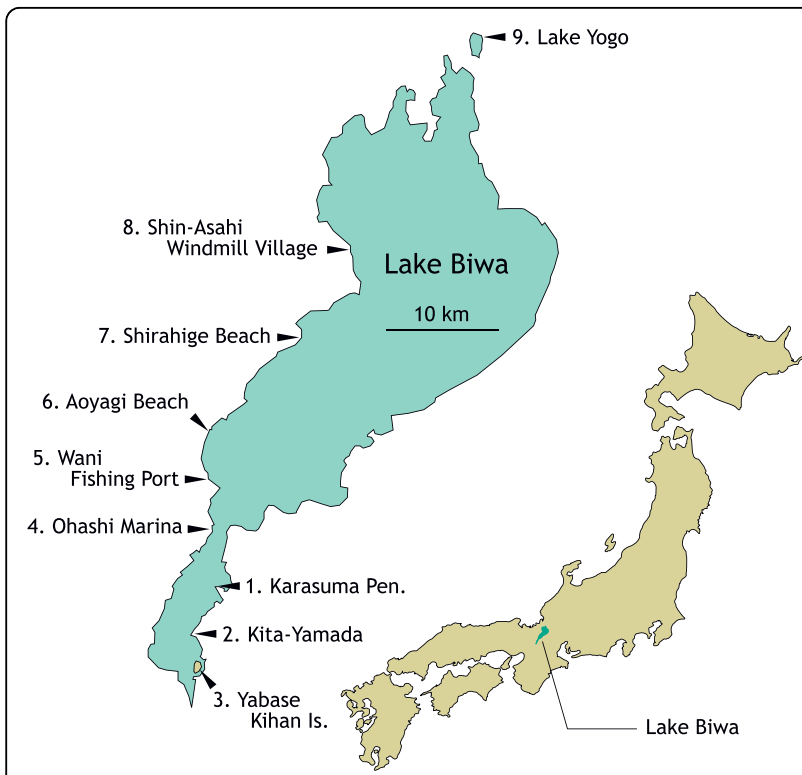

Figure $\mathbf{2}$ Locations of sampling sites. Sites numbered 1 to 4 were surveyed for seasonal transition.

\section{Results and discussion}

\section{Ecological studies of viruses in Lake Biwa}

Using two strains of algae, C. variabilis F36-ZK and $M$. reisseri SW1-ZK, we surveyed algae-lytic viruses at nine sites in Lake Biwa and Lake Yogo, both in Shiga Prefecture, western Honshu, Japan (Fig. 2), between May and July 2004. At all sites and at nearly all sampling time points, we detected viruses infecting $C$. variabilis. None of the isolated viruses infected $M$. reisseri in this study, indicating that all of those obtained were $C$. variabilis virus $(\mathrm{CvV}=\mathrm{NC64} \mathrm{A}$ virus$)$.

Since the development of a screening method for virus sampling [12], both $\mathrm{CvV}$ and $\mathrm{MrV}$ have been detected from extensive regions of the world, but $\mathrm{MrV}$ has never been recorded from East Asia [21,22]. In the present study, we also found $\mathrm{CvVs}$, but not $\mathrm{MrV}$, from the water of Lake Biwa. Van Etten [21] indicated that the factors influencing the distribution patterns of these viruses are probably latitude and altitude. Based on a series of taxonomic studies on symbiotic algae, the all $P$. bursaria collected so far in Japan have been verified as C. variabilis-harboring type [6]. The absence of $\mathrm{MrV}$ in Lake Biwa is inevitable if no M. reisseri occur in this lake.

The results of our ecological studies are summarized in Table 1 . The titers of CvVs were mostly between 0.5 and $50 \mathrm{PFU} \mathrm{mL} \mathrm{m}^{-1}$. This density level is the same or slightly lower than those reported in previous studies [e.g., [23,24]]. Exceptionally high values were recorded in May (85.3 PFU mL $\mathrm{PL}^{-1}$ ) and June (171.0 PFU mL $\mathrm{PL}^{-1}$ ) 2004 at Shin-Asahi Windmill Village (site 8). In addition, no clear seasonal changes in population density were detected, and the population densities were particularly low $\left(<1.5 \mathrm{PFU} \mathrm{mL}^{-1}\right)$ in high-temperature waters (around $30^{\circ} \mathrm{C}$ ) in July 2004 at all the sites except ShinAsahi Windmill Village.

Reisser et al. [25] attempted to explain the density of viruses in natural water environments; the viral density depends on the P. bursaria population and the probability of its burst (i.e., release of symbiotic algae). In 2003 and 2004, a major outbreak of koi herpes virus (KHV) occurred in Japan. Populations of koi (common carp) in Lake Biwa were attacked by the virus from May to June 2004, which caused mass death of the fish. Large numbers of koi carcasses washed ashore onto the coastal area of a sampling point, Shin-Asahi Windmill Village (site 8 ). At this time, shallow water around this point seemed to be under low-oxygen conditions caused by decomposition of fish carcasses. We detected the highest virus concentrations at this sampling point at these times. In contrast, lower densities of viruses were

Table 1 Seasonal transition of Chlorella variabilis viruses concentration (PFU $\mathrm{mL}^{-1}$ ) for nine sampling sites

\begin{tabular}{lllllllllll}
\hline Sampling date & Water temp. $\left({ }^{\circ} \mathbf{C}\right)$ & Site $\mathbf{1}$ & Site $\mathbf{2}$ & Site $\mathbf{3}$ & Site $\mathbf{4}$ & Site 5 & Site $\mathbf{6}$ & Site $\mathbf{7}$ & Site 8 & Site $\mathbf{9}$ \\
\hline 2004 May & - & 2.67 & 21.3 & 21.3 & 2.67 & 21.3 & 2.67 & ND & 85.3 & 21.3 \\
June & $16.5-19.5$ & 21.3 & 5.33 & 10.7 & 5.33 & 5.33 & - & 10.7 & 171.0 & 42.7 \\
July & $29.3-32.0$ & ND & 0.67 & 0.67 & ND & 1.33 & - & ND & 10.7 & 0.67 \\
Sept. & $24.0-25.5$ & 0.67 & 5.33 & 10.7 & 10.7 & - & - & - & - & - \\
Oct. & $16.0-16.9$ & 0.67 & 1.33 & 10.7 & 5.33 & - & - & - & - & - \\
Nov. & $10.2-12.0$ & 5.33 & 5.33 & 5.33 & 5.33 & - & - & - & - & - \\
Dec. & $8.8-11.2$ & 0.67 & 1.33 & 21.3 & 0.33 & - & - & - & - & - \\
2005 Jan. & $3.9-6.8$ & 21.3 & 1.33 & 0.67 & 0.67 & - & - & - & - & - \\
Feb. & $5.2-8.3$ & 1.33 & 1.33 & 10.7 & 5.33 & - & - & - & - & - \\
Mar. & $8.0-9.4$ & 5.33 & 10.7 & 21.3 & 5.33 & - & - & - & - & - \\
Apr. & $17.0-18.8$ & 5.33 & 21.3 & 21.3 & 5.33 & - & - & - & - & - \\
June & $23.0-24.0$ & 5.33 & 10.7 & 42.7 & 10.7 & - & - & - & -
\end{tabular}

Sampling Sites: 1. Karasuma Pen., 2. Kita-Yamada, 3. Yabase Kihan Is., 4. Ohashi Marina, 5. Wani Fishing Port, 6. Aoyagi Beach, 7. Shirahige Beach, 8. Shin-Asahi Windmill Village, 9. Lake Yogo (also see Fig. 2). ND: Not detected. -: Not determined. 


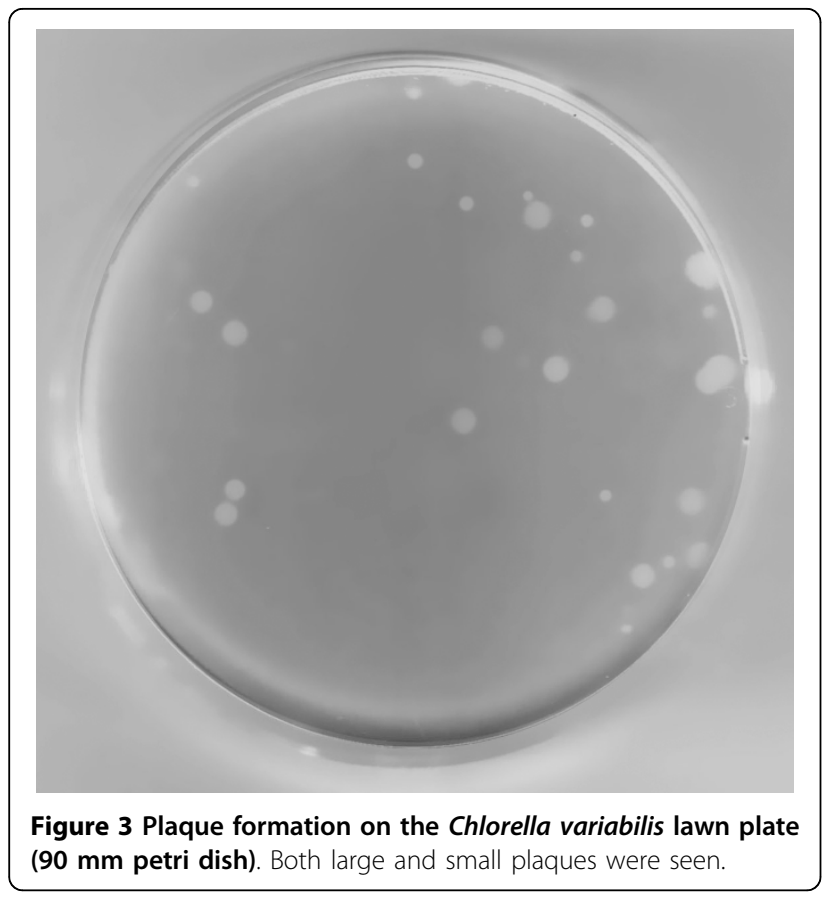

common in July 2004 at all sampling points (Table 1). In general, high temperature and strong light prompt Paramecium to avoid its translatory movement. Low oxygen levels may have caused bursting of some $P$. bursaria cells, with summer heat prompting the migration of $P$. bursaria.

\section{Plaque-forming assay}

We performed plaque-forming assay of the viruses, and all but one plate revealed plaques 3 to $4 \mathrm{~mm}$ in diameter. The exceptional plate, for the sample water from Ohashi Marina (site 4, May 2004), had smaller plaques (about $1 \mathrm{~mm}$ in diameter) in addition to the normalsized plaques (Fig. 3). Viruses recovered from one of the smaller plaques formed smaller plaques on reinfection. By repeating this procedure several times, we concluded that we had established a pure clone of smaller plaqueforming virus, which we designated $\mathrm{CvV}$-BW1. We subsequently focused our attention on the biological characteristics of $\mathrm{CvV}-\mathrm{BW} 1$. We used four independent clones of normal-sized plaque-forming viruses, $\mathrm{CvV}$ BW2, -BW3, -BW4, and -BW5, obtained in the same ecological study. These $\mathrm{CvV}-\mathrm{BW}$ strains infect $C$. variabilis NC64A but not M. reisseri. Similar to known CvVs, CvV-BW1 appeared as polyhedral particles about $150 \mathrm{~nm}$ in diameter (Fig. 4).

\section{Protein of CvV-BW1}

First, we analyzed the protein composition of $\mathrm{CvV}$-BW1 by SDS-PAGE. As shown in Fig. 5, when viral proteins were not heat-treated (leftmost lane), two major bands,
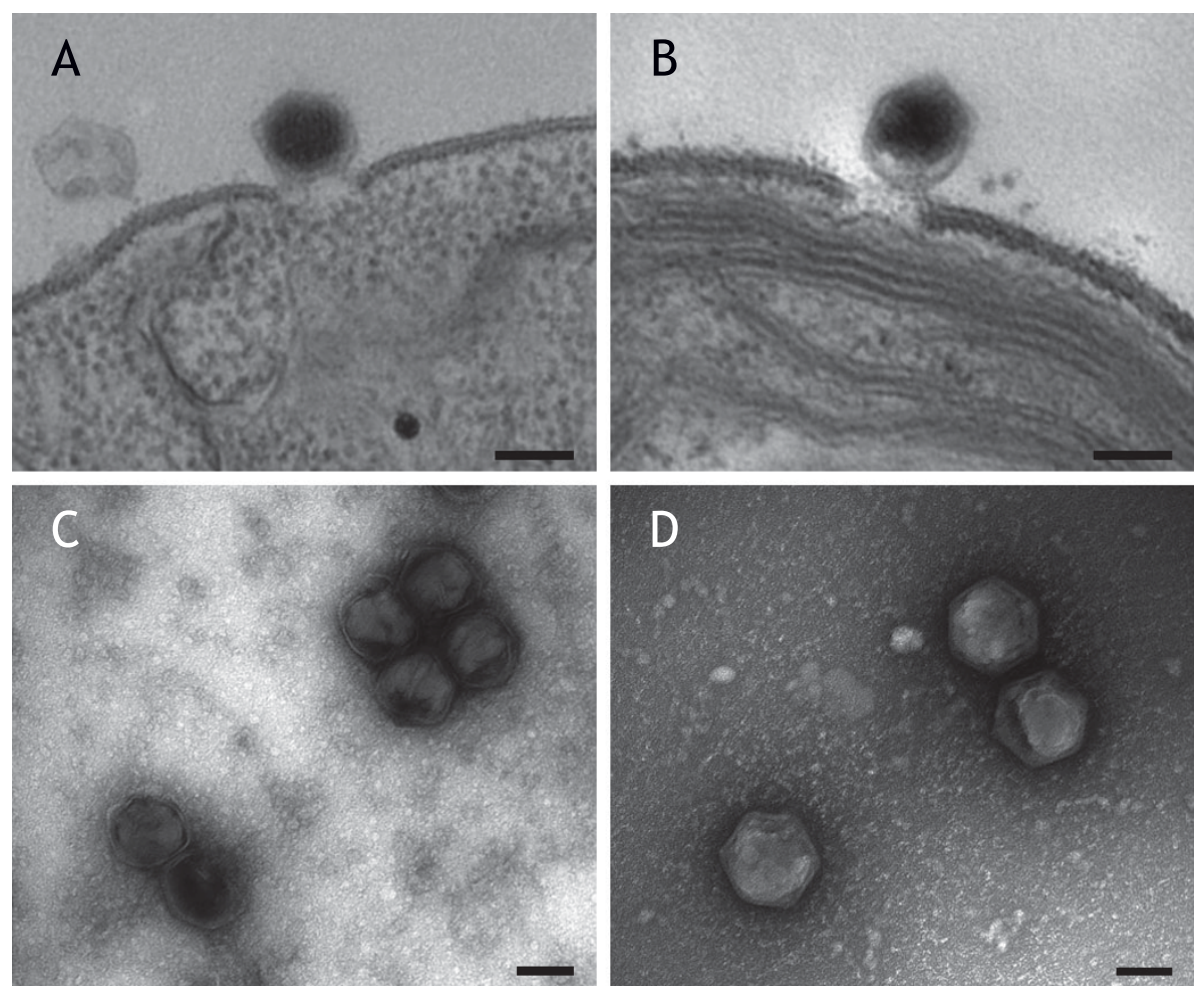

Figure 4 Polyhedral particles, attaching to the external surface of the algal cell wall (TEM, upper panel) and released particles (SEM, lower panel) of Chlorella variabilis virus. CVV-BW1 is on the left (A and C) and CVV-BW3 is on the right (B and D). Scale bars are $100 \mathrm{~nm}$. 


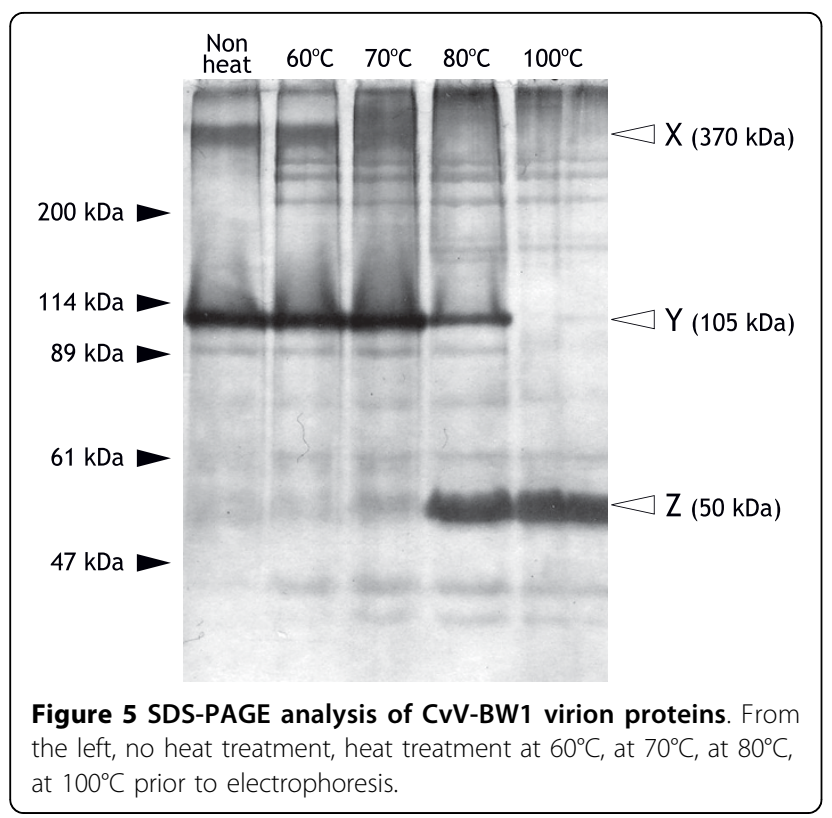

designated $\mathrm{X}$ and $\mathrm{Y}$, were observed. Judging from the intensity, the proteins in these bands accounted for $80 \%$ of the total viral proteins. By increasing the temperature of the heat treatment to $70^{\circ} \mathrm{C}$, band $\mathrm{X}$ faded, whereas the intensity of band $\mathrm{Y}$ increased. With further increases in temperature, band $Y$ faded, whereas the intensity of band $\mathrm{Z}$ increased; with heat treatment at $100^{\circ} \mathrm{C}$, only band $\mathrm{Z}$ was observed. The sizes of proteins in bands $\mathrm{X}$, $\mathrm{Y}$, and $\mathrm{Z}$ were estimated to be $370 \mathrm{kDa}, 105 \mathrm{kDa}$, and $50 \mathrm{kDa}$, respectively, compared to size markers. To identify proteins of these bands, we performed an Nterminal amino acid sequence analysis. Although we did not obtain meaningful results for protein of band X, presumably due to an insufficient amount of protein, we obtained the same sequence, AGGLSQLVAYGAQDV, for the proteins recovered from bands $\mathrm{Y}$ and $\mathrm{Z}$. The obtained $\mathrm{N}$-terminal amino acid sequence was completely identical to those of the major capsid proteins of all PVCVs (NA46A virus and Pbi virus) reported to date. Therefore, we concluded that $\mathrm{CvV}$-BW1 has a major capsid protein of $50 \mathrm{kDa}$. We thus contended that band $\mathrm{Y}$ represent dimmer of the $50 \mathrm{kDa}$ major capsid protein. The assignment of protein of band $\mathrm{Z}$ remained to be established. In addition, CvV-BW1 showed at least nine distinct bands, which showed no changes in electrophoretic mobility according to heat treatment conditions. Further studies are required to characterize the proteins corresponding to these bands.

\section{Size of CvV-BW1 DNA}

To estimate the size of CvV-BW1 DNA, we carried out pulsed-field gel electrophoresis as described in the Methods section. The results are shown in Fig. 6 .
Compared to Saccharomyces cerevisiae chromosomes and $\lambda$ DNA ladder, we concluded that the CvV-BW1 DNA is $370 \mathrm{~kb}$ in length, assuming that it has a linear DNA genome. $\mathrm{CvV}-\mathrm{BW} 1 \mathrm{DNA}$ was somewhat larger than those of CvV-BW2, -BW3, and -BW4.

\section{Resistance/susceptibility of CvV-BW1 DNA to restriction enzymes}

$\mathrm{CvV}$ has been divided into 16 "species" based on the restriction enzyme digestion patterns and various other characteristics [3]. We attempted to cut the DNA of $\mathrm{CvV}-\mathrm{BW}$ strains using six widely used restriction enzymes: HindIII, BamHI, EcoRI, MssI, SfiI, and SwaI (Fig. 7). The results indicated that CvV-BW1 DNA was much more resistant to cleavage than the DNAs of other BW strains. That is, CvV-BW1 DNA was cut only by $M s s \mathrm{I}$ and $S w a \mathrm{I}$, while CvV-BW2, -BW3, and -BW5 DNAs were effectively cut by all six enzymes tested. DNAs of CvV-BW2 and -BW5 showed the same band pattern, indicating that they are clones of a single species.

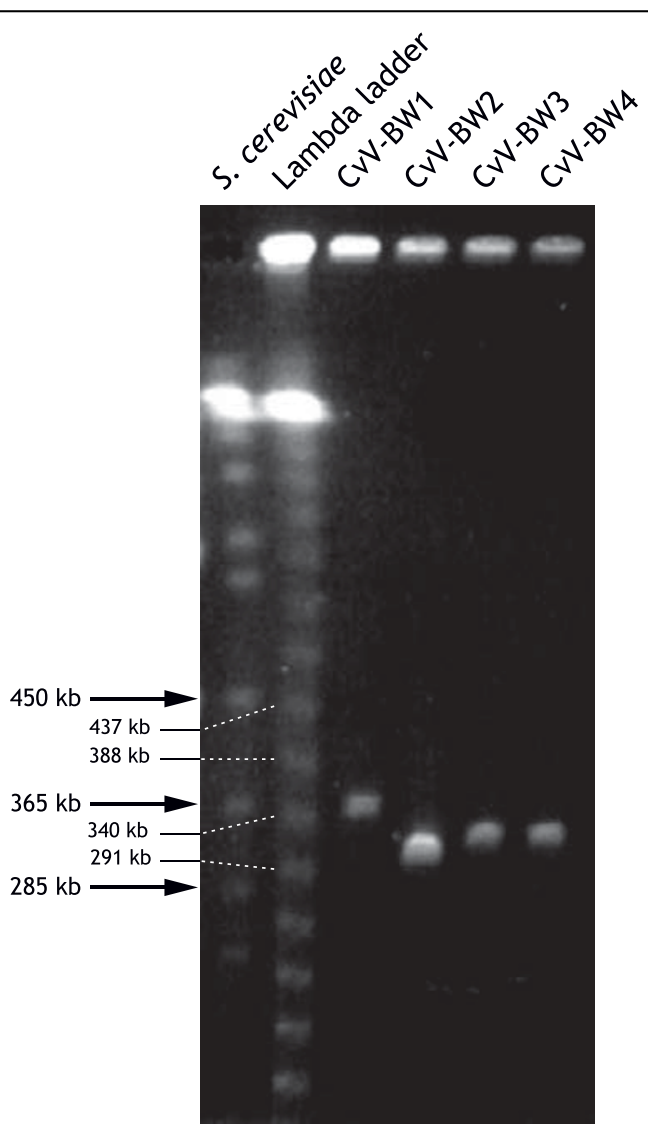

Figure 6 Estimates of virion genome sizes. From the left, Saccharomyces cerevisiae chromosomes (Bio-Rad), $\lambda$ DNA ladder (Bio-Rad), CVV-BW1, CVV-BW2, CVV-BW3, and CVV-BW4. 


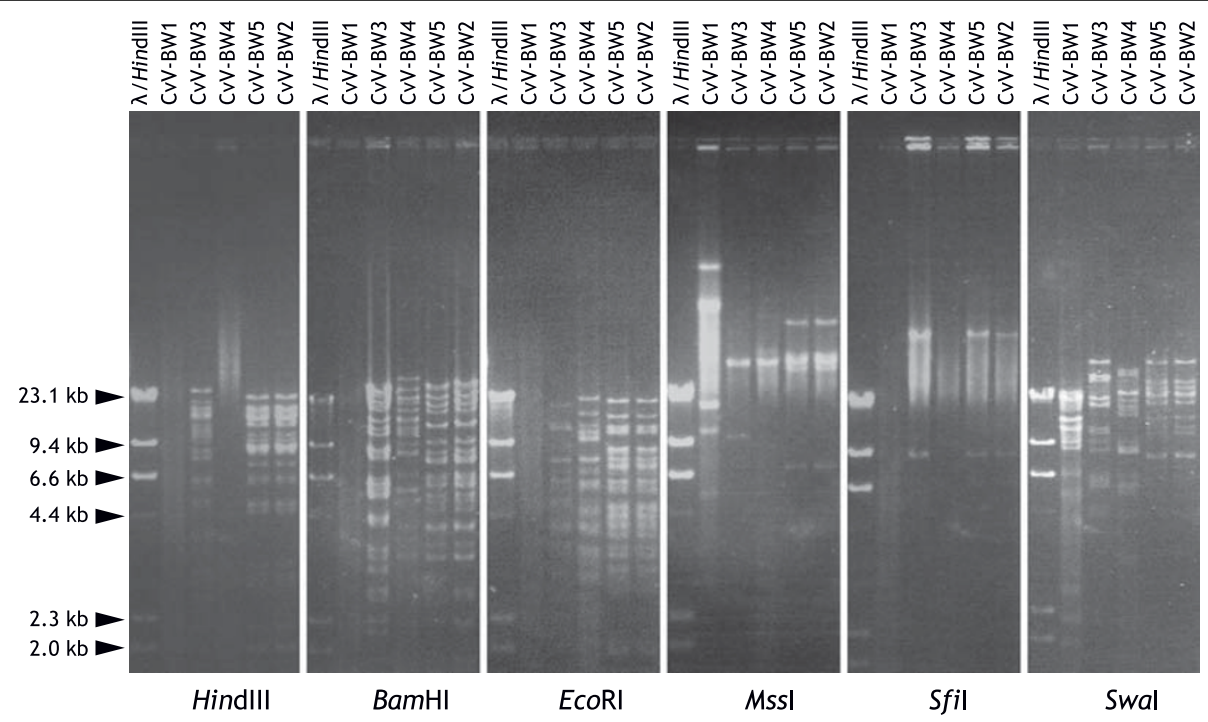

Figure 7 Restriction enzyme digestion of CvV-BW virion genomes.

An additional 18 restriction enzymes were tested for CvV-BW1 DNA; 11 of the enzymes did not effectively cut CvV-BW1 DNA (Fig. 8). The enzymes that did not effectively cut $\mathrm{CvV}-\mathrm{BW} 1 \mathrm{DNA}$ are listed in Table 2 (Enzymes I), while those that cut CvV-BW1 DNA are shown in Table 3 (Enzymes II). Van Etten et al. [3] classified $\mathrm{CvV}$ DNAs into 11 restriction groups (A to $\mathrm{K}$ ) based on the effects of 13 restriction enzymes. Although the enzymes they used were not identical to those applied here, some were common to the two studies. Judging from the cleavage patterns with the common

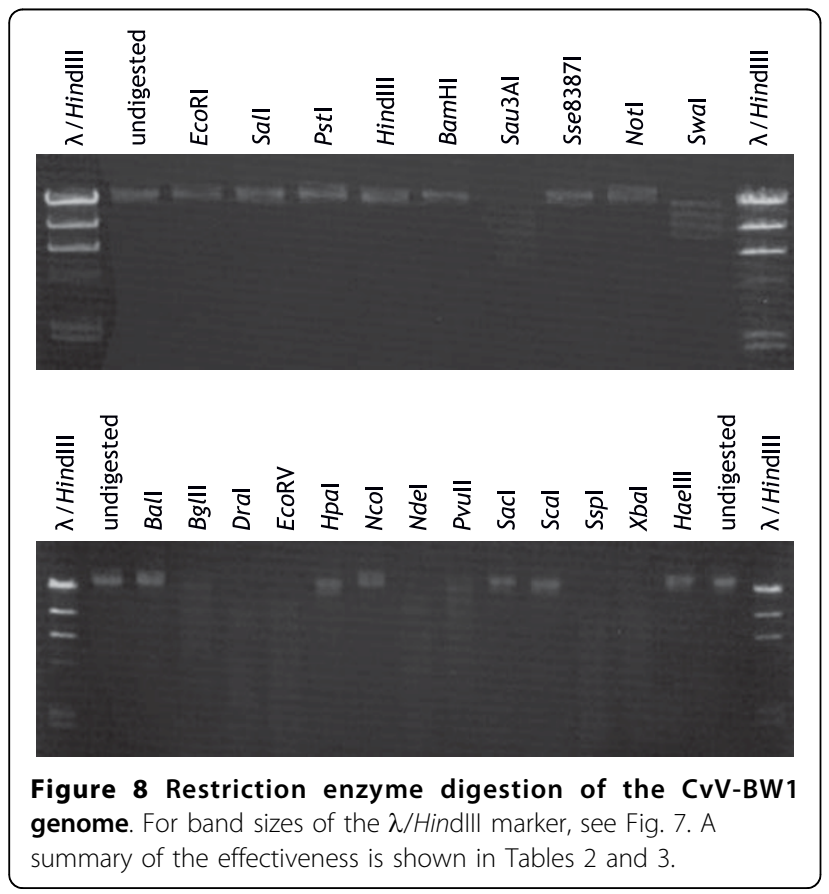

enzymes, we concluded that $\mathrm{CvV}$-BW1 DNA belongs to group $\mathrm{H}$, which is characterized by resistance to EcoRI but susceptibility to BglII.

Analysis of the enzymes of I and II indicated that the AT/GC ratio of the recognition sequences was quite different between them; enzymes I were rich (almost 65\%) in GC, whereas enzymes II were rich (75\%) in AT. This result can be rationalized in two ways: $\mathrm{CvV}$-BW1 DNA is rich in $\mathrm{AT}$ and poor in GC or CvV-BW1 DNA is highly modified at $\mathrm{G}$ and/or $\mathrm{C}$. Nucleotide sequence analysis of clones in the $\mathrm{CrV}$-BW1 genome library did not reveal any evidence that CvV-BW1 DNA was ATrich; according to our preliminary genome analysis, the GC content of CvV-BW1 is in the vicinity of $41.3 \%$.

Table 2 Restriction enzymes that did not effectively cut CvV-BW1 DNA (Enzymes I)

\begin{tabular}{ll}
\hline Restriction enzyme & Recognition sequence \\
\hline Ball & TGGCCA \\
BamHI & GGATCC \\
EcoRl & GAATTC \\
Haelll & RGCGCY \\
Hindlll & AAGCTT \\
Hpal & GTAAC \\
Ncol & CCATGG \\
Notl & GCGGCCGC \\
Pstl & CTGCAG \\
Pvull & CAGCTG \\
Sacl & GAGCTC \\
Sall & GTCGAC \\
Scal & AGTACT \\
Sfil & GGCCNNNNNGGCC \\
Sse8387l & CCTGCAGG \\
\hline
\end{tabular}


Table 3 Restriction enzyme that effectively cut CvV-BW1 DNA (Enzymes II)

\begin{tabular}{ll}
\hline Restriction enzyme & Recognition sequence \\
\hline Bgll & AGATCT \\
Dral & TTAAA \\
EcoRV & GATATC \\
Ndel & CATATG \\
Mssl & GTTAAAC \\
Sau3Al & GATC \\
Sspl & ACTAGT \\
Swal & ATTAAAT \\
Xbal & TCTAGA \\
\hline
\end{tabular}

Therefore, we suspected that CvV-BW1 DNA would have a high incidence of $\mathrm{G}$ and/or $\mathrm{C}$ modification. To confirm this speculation, we examined the frequencies of modified nucleotides in CvV-BW1 DNA; the results revealed $33.2 \% 5 \mathrm{mC}$ relative to $5 \mathrm{mC}+\mathrm{C}$ and $31.0 \% 6$ $\mathrm{mA}$ relative to $6 \mathrm{~mA}+\mathrm{A}$.

\section{Production of hyaluronan by CvV-BW1}

The best characterized $\mathrm{CvV}, \mathrm{PBCV}-1$, encodes hyaluronan synthase (HAS), which functions in the production of hyaluronan, a polysaccharide covering the outside of the algal cell wall [26]. Graves et al. [16] showed that some $\mathrm{CvVs}$ produce hyaluronan during infection, although others do not [27]. Therefore, we examined whether $\mathrm{CvV}-\mathrm{BW} 1$ produces hyaluronan. Algal cells showed strong fluorescence $120 \mathrm{~min}$ after infection of $\mathrm{CvV}-\mathrm{BW} 1$ (stronger than those infected by CvV-BW3) using the streptavidin-biotin system, indicating the production of hyaluronan by CvV-BW1 (Fig. 9).

\section{DNA polymerase gene phylogeny of CvV-BW1}

The DNA polymerase genes, dnapol, of viruses appear to have evolved from a common ancestral gene, and are

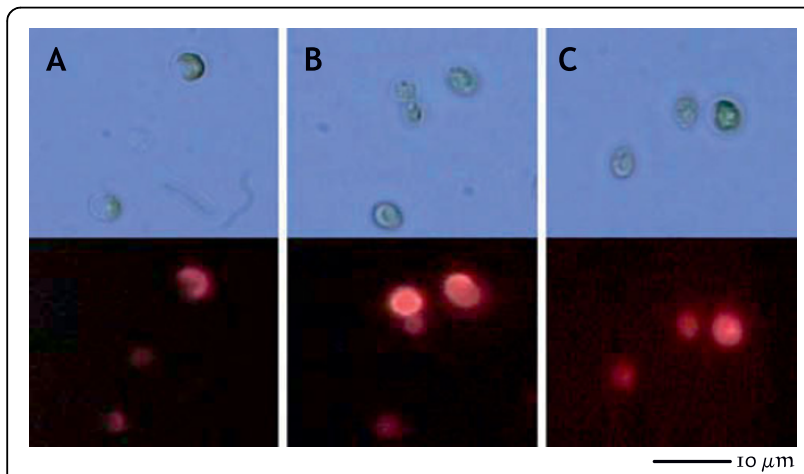

Figure 9 Light (upper) and fluorescence (lower) images of Chlorella variabilis. A: Noninfected algae. Slight fluorescence assumed to be intrinsic fluorescence of the chloroplast; B: CVV-BW1infected algae; C: CVV-BW3-infected algae. highly conserved within the viral family Phycodnaviridae $[28,29]$. Therefore, we attempted to amplify a homolog from $\mathrm{CvV}-\mathrm{BW} 1$ via PCR using sequences that are common to nearly all strains, with PBCV-1, NY-2A, and CVK2 as primers (Fig. 10). The amplification fragment of 2060 bp obtained by PCR was then sequenced (AB572585). Multiple alignment with the known PBCV dnapol sequences indicated that this 2060-bp fragment contained an intron of $86 \mathrm{bp}$. Introns of the same length are present in dnapol of AR-158, NY-2A, NY-2B, and NYs-1 [18]. In the phylogenetic tree constructed from the exon regions of dnapol, $\mathrm{CvV}$ was found to be divided into two clades, $\mathrm{A}$ and $\mathrm{B}$, with a minimum

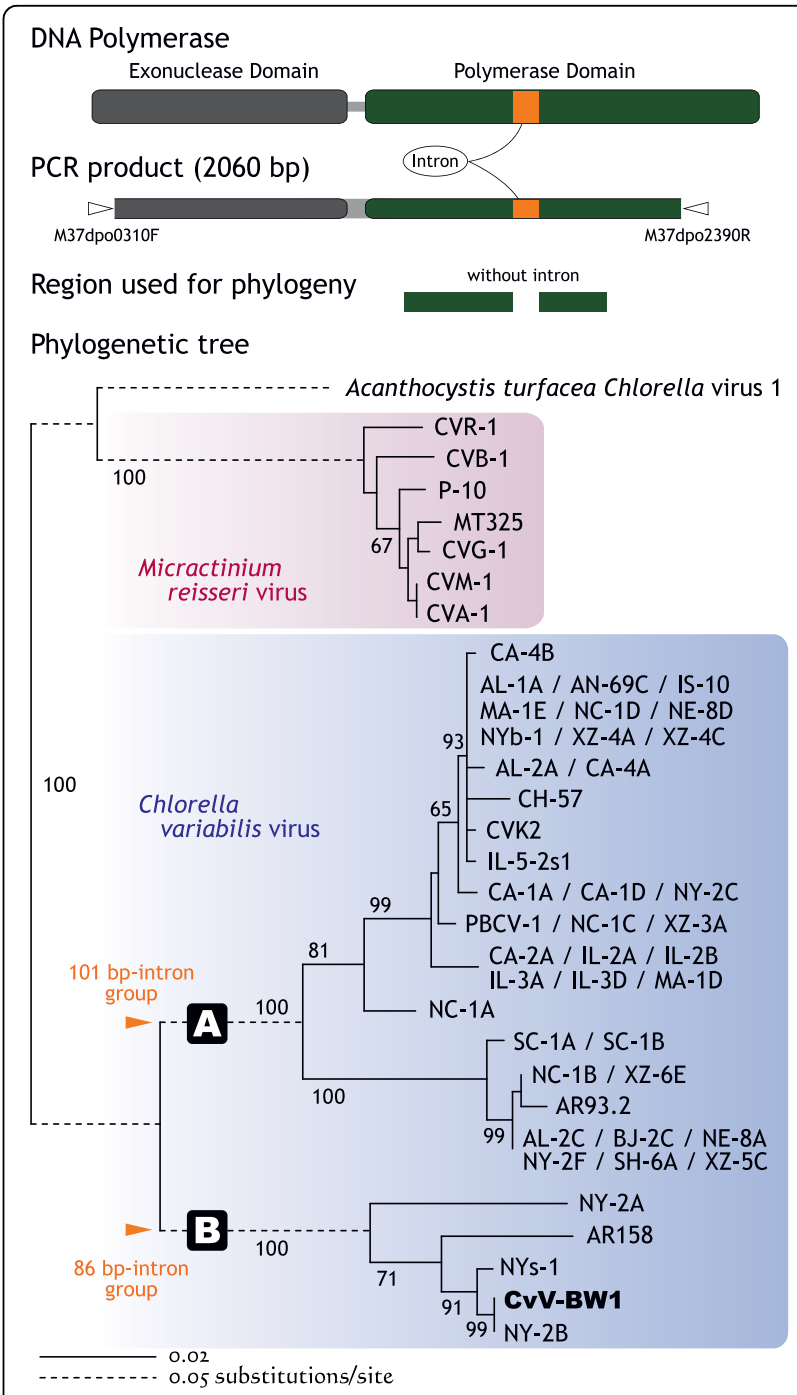

Figure 10 Domain structure of the dnapol gene, obtained sequence, and neighbor-joining tree of PBCVs based on dnapol gene sequences. Chlorella variabilis virus split into two lineages, A (101 bp intron group) and B (86 bp intron group). Numbers at major nodes represent bootstrap probabilities (1000 replicates). 
distance of 0.237 between these clades. As shown in Fig. 10 , all $\mathrm{CvVs}$ with the 86-bp intron belonged to the same group that included $\mathrm{CvV}-\mathrm{BW} 1$ affiliated to clade $\mathrm{B}$, while all $\mathrm{CvVs}$ affiliated to clade A possessed an intron of $101 \mathrm{bp}$ in their dnapol genes.

\section{Identity of CvV-BW1}

Van Etten et al. [3] reported that three viral strains, CA$4 \mathrm{~A}, \mathrm{XZ}-4 \mathrm{~A}$, and $\mathrm{XZ}-5 \mathrm{C}$, belong to restriction group $\mathrm{H}$. Note that these strains all form small plaques $(1 \mathrm{~mm}$ in diameter) and are rich in methylated nucleotides (40\% to $45 \% 5 \mathrm{mC}$ among $\mathrm{C}+5 \mathrm{mC}$, and $20 \%$ to $30 \% 6 \mathrm{~mA}$ among $\mathrm{A}+6 \mathrm{~mA})$. As presented above, $\mathrm{CvV}$-BW1 shares these properties. However, all the strains belonged to dnapol clade A (101-bp intron group) (Fig. 10). Members of dnapol clade B (86-bp intron group) differ from $\mathrm{CvV}-\mathrm{BW} 1$ in some respects. NY-2A belongs to restriction group I, NYs-1 belongs to group F, and NY-2B belongs to group $\mathrm{G}$. Although the restriction group of AR158 has not been determined, AR158 does not encode HAS [30]. Taken together, these findings indicate that $\mathrm{CvV}-\mathrm{BW} 1$ does not belong to any of the 16 $\mathrm{CvV}$ "species" defined to date.

\section{Conclusions}

We detected C. variabilis virus (NC64A virus) but not M. reisseri virus (Pbi virus) in the water of Lake Biwa, Japan. The highest virus density was recorded in water under low-oxygen conditions, whereas lower virus densities were commonly found in the seasons when the lake waters reached up to around $30^{\circ} \mathrm{C}$. These results suggest that viral density is affected by the population density of $P$. bursaria and its burst ratio.

The viral strain CvV-BW1 found in Lake Biwa was examined in detail with regard to plaque size, electron microscopic features, protein composition, genome size, restriction enzyme digestion, level of DNA methylation, production of hyaluronan, and phylogeny of the DNA polymerase gene. Taken together, all of these observations indicate that $\mathrm{CvV}-\mathrm{BW} 1$ is likely to be a new species of $C$. variabilis virus.

\section{List of abbreviations used}

CvV: Chlorella variabilis virus; MrV: Micractinium reisseri virus; PBCV: Paramecium bursaria Chlorella virus

\section{Competing interests}

The authors declare that they have no competing interests.

\section{Authors' contributions}

MS screened and isolated the viral strains, and then tested hyaluronan productivity. YK observed viruses by electron microscopy. SiU carried out the protein analysis. YM examined the viral genome sizes, and then MS and YM confirmed the results of restriction enzyme digestion. $\mathrm{YH}$ examined viral DNA modification. $\mathrm{RH}$ contributed to DNA polymerase gene analyses. $\mathrm{RH}$ and $\mathrm{BiO}$ prepared the manuscript. $\mathrm{NI}$ initially conceived of this study and $\mathrm{RH}$,
$\mathrm{MK}, \mathrm{BiO}, \mathrm{NI}$ finalized the experimental design. All authors have read and approved the final manuscript.

\section{Authors' information}

1 Department of Biomedical Science, College of Life Sciences, Ritsumeikan University, Noji Higashi 1-1-1, Kusatsu, 525-8577 Japan.

2 Department of Bioscience and Biotechnology, Faculty of Science and Engineering, Ritsumeikan University, Noji Higashi 1-1-1, Kusatsu, 525-8577 Japan.

3 Department of Biotechnology, College of Life Sciences, Ritsumeikan University, Noji Higashi 1-1-1, Kusatsu, 525-8577 Japan.

4 Department of Pharmacy, College of Pharmaceutical Sciences, Ritsumeikan University, Noji Higashi 1-1-1, Kusatsu, 525-8577 Japan.

\section{Acknowledgements}

We thank Associate Prof. T. Suzaki (Kobe University) for help with electron microscopy.

\section{Author details}

${ }^{1}$ Department of Biomedical Science, College of Life Sciences, Ritsumeikan University, Noji Higashi 1-1-1, Kusatsu, 525-8577 Japan. ²Department of Bioscience and Biotechnology, Faculty of Science and Engineering, Ritsumeikan University, Noji Higashi 1-1-1, Kusatsu, 525-8577 Japan. ${ }^{3}$ Department of Biotechnology, College of Life Sciences, Ritsumeikan University, Noji Higashi 1-1-1, Kusatsu, 525-8577 Japan. ${ }^{4}$ Department of Pharmacy, College of Pharmaceutical Sciences, Ritsumeikan University, Noji Higashi 1-1-1, Kusatsu, 525-8577 Japan.

Received: 20 July 2010 Accepted: 13 September 2010

Published: 13 September 2010

\section{References}

1. Meints $R H$, Van Etten $J L$, Kuczmarski D, Lee $K$, Ang B: Viral infection of the symbiotic Chlorella-like alga present in Hydra viridis. Virology 1981, 113:698-703.

2. Van Etten JL, Meints RH, Kuczmarski D, Burbank DE, Lee K: Viruses of symbiotic Chlorella-like algae isolated from Paramecium bursaria and Hydra viridis. Proc Natl Acad Sci USA 1982, 79:3867-3871.

3. Van Etten JL, Lane LC, Meints RH: Viruses and viruslike particles of eukaryotic algae. Microbiol Rev 1991, 55:586-620.

4. Bubeck JA, Pfitzner AJP: Isolation and characterization of a new type of chlorovirus that infects an endosymbiotic Chlorella strain of the heliozoon Acanthocystis turfacea. J Gen Virol 2005, 86:2871-2877.

5. Hoshina $R$, Imamura N: Multiple origins of the symbioses in Paramecium bursaria. Protist 2008, 159:53-63.

6. Hoshina R, Iwataki M, Imamura N: Chlorella variabilis and Micractinium reisseri sp. nov. (Chlorellaceae, Trebouxiophyceae): redescription of the endosymbiotic green algae of Paramecium bursaria (Peniculia, Oligohymenophorea) in the 120th year. Phycol Res 2010, 58:188-201.

7. Kamako S-i, Hoshina R, Ueno S, Imamura N: Establishment of axenic endosymbiotic strains of Japanese Paramecium bursaria and the utilization of carbohydrate and nitrogen compounds by the isolated algae. Eur J Protistol 2005, 41:193-202.

8. Hoshina R, Imamura N: Phylogenetically close group I introns with different positions among Paramecium bursaria photobionts imply a primitive stage of intron diversification. Mol Biol Evol 2009, 26:1309-1319.

9. Hoshina R, Kamako S-i, Imamura N: Phylogenetic position of endosymbiotic green algae in Paramecium bursaria Ehrenberg from Japan. Plant Biol 2004, 6:447-453.

10. Hoshina R, Kato Y, Kamako S-i, Imamura N: Genetic evidence of "American" and "European" type symbiotic algae of Paramecium bursaria Ehrenberg. Plant Biol 2005, 7:526-532.

11. Ichimura T: Sexual cell division and conjugation-papilla formation in sexual reproduction of Closterium strigosum. In Proceedings of the Seventh International Seaweed Symposium: August 1971; Hokkaido. Edited by: Nishizawa K, Arasaki S, Chihara M, Hirose H, Nakamura V, Tsuchiya Y. Tokyo: University of Tokyo Press; 1971:208-214.

12. Van Etten JL, Burbank DE, Kuczmarski D, Meints $R H$ : Virus infection of culturable Chlorella-like algae and development of a plaque assay. Science 1983, 219:994-996. 
13. Sambrook J, Fritsch EF, Maniatis T: Molecular Cloning: A Laboratory Manual. NY: Cold Spring Harbor Laboratory press, 21989.

14. Kowalak JA, Bruenger E, Hashizume T, Peltier JM, Ofengand J, McCloskey JA: Structural characterization of U*-1915 in domain IV from Escherichia coli $23 \mathrm{~S}$ ribosomal RNA as 3-methylpseudouridine. Nucleic Acids Res 1996, 24:688-693.

15. Ushida C, Muramatsu T, Mizushima H, Ueda T, Watanabe K, Stetter KO, Crain PF, McCloskey JA, Kuchino Y: Structural feature of the initiator tRNA gene from Pyrodictium occultum and the thermal stability of its gene product, $\mathrm{RRNA}_{\mathrm{i}}^{\text {Met }}$. Biochimie 1996, 78:847-855.

16. Graves MV, Burbank DE, Roth $\mathrm{R}$, Heuser J, DeAngelis PL, Van Etten JL: Hyaluronan synthesis in virus PBCV-1-infected Chlorella-like green algae. Virology 1999, 257:15-23.

17. Cohen M, Klein E, Geiger B, Addadi L: Organization and adhesive properties of the hyaluronan pericellular coat of chondrocytes and epithelial cells. Biophys J 2003, 85:1996-2005.

18. Zhang Y, Adams B, Sun L, Burbank DE, Van Etten JL: Intron conservation in the DNA polymerase gene encoded by Chlorella viruses. Virology 2001, 285:313-321.

19. Larkin MA, Blackshields G, Brown NP, Chenna R, McGettigan PA, McWilliam H, Valentin F, Wallace IM, Wilm A, Lopez R, Thompson JD, Gibson TJ, Higgins DG: Clustal W and Clustal X version 2.0. Bioinformatics 2007, 23:2947-2948.

20. Tamura K, Dudley J, Nei M, Kumar S: MEGA4: Molecular Evolutionary Genetics Analysis (MEGA) software version 4.0. Mol Biol Evol 2007, 24:1596-1599.

21. Van Etten JL: Unusual life styoe of giant chlorella viruses. Annu Rev Genet 2003, 37:153-195.

22. Yamada T, Onimatsu H, Van Etten JL: Chlorella viruses. Adv Virus Res 2006 , 66:293-336.

23. Van Etten JL, Van Etten $\mathrm{CH}$, Johnson JK, Burbank DE: A survey for viruses from fresh water that infect a eukaryotic chlorella-like green alga. Appl Environ Microbiol 1985, 49:1326-1328.

24. Yamada T, Higashiyama T, Fukuda T: Screening of natural waters for viruses which infect chlorella cells. Appl Environ Microbiol 1991, 57:3433-3437.

25. Reisser W, Becker B, Klein T: Studies on ultrastructure and host range of a Chlorella attacking virus. Protoplasma 1986, 135:162-165.

26. DeAngelis $\mathrm{PL}$, Jing W, Graves MV, Burbank DE, Van Etten JL: Hyaluronan synthase of Chlorella virus PBCV-1. Science 1997, 278:1800-1803.

27. Mohammed Ali AM, Kawasaki T, Yamada T: Genetic rearrangements on the Chlorovirus genome that switch between hyaluronan synthesis and chitin synthesis. Virology 2005, 342:102-110.

28. Lee AM, Ivey RG, Meints RH: The DNA polymerase gene of a brown algal virus: structure and phylogeny. J Phycol 1998, 34:608-615.

29. Schroeder DC, Oke J, Malin G, Wilson WH: Coccolithovirus (Phycodnaviridae): Characterisation of a new large dsDNA algal virus that infects Emiliania huxleyi. Arch Virol 2002, 147:1685-1698.

30. Fitzgerald LA, Graves MV, Li X, Feldblyum T, Nierman WC, Van Etten JL: Sequence and annotation of the 369-kb NY-2A and the 345-kb AR158 viruses that infect Chlorella NC64A. Virology 2007, 358:472-484.

doi:10.1186/1743-422X-7-222

Cite this article as: Hoshina et al:: Isolation and characterization of a virus (CvV-BW1) that infects symbiotic algae of Paramecium bursaria in Lake Biwa, Japan. Virology Journal 2010 7:222.

\section{Submit your next manuscript to BioMed Central and take full advantage of:}

- Convenient online submission

- Thorough peer review

- No space constraints or color figure charges

- Immediate publication on acceptance

- Inclusion in PubMed, CAS, Scopus and Google Scholar

- Research which is freely available for redistribution

Submit your manuscript at www.biomedcentral.com/submit 